\title{
Meta-analysis of randomised controlled trials of selective decontamination of the digestive tract
}

\author{
Selective Decontamination of the Digestive Tract Trialists' Collaborative Group
}

Abstract

Objective-To determine the clinical benefits of selective decontamination of the digestive tract in patients treated in intensive care units.

Design-Meta-analysis of 22 randomised trials that compared different combinations of oral nonabsorbable antibiotics, with or without a systemic component, with no treatment in controls.

Subjects-4142 patients seen in general and specialised intensive care units around the world. 2047 received some form of antibiotic treatment, the remainder no prophylaxis.

Data analysis-Each trial was reviewed through direct contact with study investigators. Data collected were: the randomisation procedure, number of patients, number excluded from the analysis, and numbers of respiratory tract infections and deaths. Data were combined according to an intention to treat analysis with the Mantel-Haenszel-Peto method.

Main outcome measures-Respiratory tract infections and total mortality.

Results-Selective decontamination of the digestive tract significantly reduced respiratory tract infections (odds ratio $0.37 ; 95 \%$ confidence interval 0.31 to $0 \cdot 43)$. The value of the common odds ratio for total mortality $(0.90 ; 0.79$ to 1.04$)$ suggested at best a moderate treatment effect, reaching statistical significance only when the subgroup of trials of topical and systemic treatment combined was considered separately (odds ratio $0.80 ; 0.67$ to 0.97 ). No firm conclusions could be drawn owing to large variations in patient $\mathrm{mix}$ and severity within and between trials.

Conclusions-The findings strongly indicate that selective decontamination significantly reduces infection related morbidity in patients receiving intensive care. They also highlight why definite conclusions about the effect of prophylaxis on mortality cannot be drawn despite the large number of trials available. Based on the most favourable results obtained by pooling data from trials in which combined topical and systemic treatment was used it may be estimated that 6 (range 5-9) and 23 (13-139) patients would need to be treated to prevent one respiratory tract infection and one death respectively.

Correspondence to: The Secretariat, Selective Decontamination of the Digestive Tract Trialists' Collaborative Group, Laboratorio di Epidemiologia Clinica, Istituto Mario Negri, Via Eritrea 62, 20157 Milan, Italy.

$B M F$ 1993;307:525-32 aimed at preventing them. One such strategy selectively decontaminating the digestive tract. This is designed to prevent infection by eradicating and preventing carriage of aerobic potentially pathogenic micro-organisms from the oropharynx, stomach, and gut. Selective decontamination with combined oral non-absorbable and systemic antibiotics was first reported in 1984 by Stoutenbeek et al in a group of multiple trauma patients. ${ }^{1}$ The incidence of nosocomial infection was reduced from $81 \%$ to $16 \%$ in a non-randomised comparison with a historical control group.' Other studies have tested the efficacy of selective decontamination in intensive care unit patients, using infection related morbidity as the main end point. Results suggest that selective decontamination may reduce infection, but it is not clear whether there is a corresponding effect on mortality. These conclusions have recently been supported by a metaanalysis ${ }^{2}$ based on six randomised and six nonrandomised trials which confirmed that selective decontamination is effective in preventing infections. ${ }^{2}$ That study, however, had insufficient power to detect the extent of the reduction in relative mortality (10$20 \%$ ) that is now seen as appropriate when the treatment is applied to heterogeneous populations of intensive care unit patients.

In preparation for the first European consensus conference on selective decontamination of the digestive trace, held in Paris in December 1991, a preliminary meta-analysis based on international collaboration among trialists was started. The findings presented at the conference ${ }^{3}$ showed an effect of selective decontamination on infection but not on mortality. ${ }^{4}$ This collaboration has continued and new trials have been traced. We report the results of this extended meta-analysis and discuss the implications in terms of end points and sample size requirements for design of future confirmatory studies.

\section{Methods}

STUDIES SEARCH AND SELECTION

We planned to analyse all randomised controlled trials of selective decontamination for the prevention of respiratory tract infections and death in intensive care unit patients. Only randomised trials were considered because otherwise control of selection bias cannot be guaranteed. Studies reported from January 1984 till June 1992 were identified by literature search Medline (mesh keywords "intensive care units"; "critical care"; "antibiotics combined therapeutic use"; "antibiotics combined administration and dosage"; "respiratory tract infections prevention and control"). This detected randomised controlled trials which compared selective decontamination of the digestive tract with placebo or no treatment. The organiser of the first European consensus conference on intensive care medicine also provided a list of all investigators who had ever published on the topic. At the time of the conference 17 trials were available. ${ }^{5}$ An international secretariat was then established to trace other completed but unpublished trials. This further search examined proceedings of meetings held on selective decon- 
tamination until June 1992 and made personal contact with workers in the field. All collaborating trialists were asked to indicate ongoing trials of which they were aware. No formal search was made through pharmaceutical companies. By this process eight additional trials were traced. Material used to trace studies, including proceedings of meetings at which data were presented, is available from the coordinating centre.

To test the validity of data all participants were asked to provide in standardised written form specific information independent of the publication status of their work. The following data were requested separately for each treatment arm: (a) number of patients and method of randomisation; $(b)$ percentages of medical, surgical, and trauma patients; (c) number of patients with respiratory tract infections; (d) number of deaths recorded so far; $(e)$ number of patients, if any, excluded from the final analysis in order to allow an "intention to treat analysis" and (f) number of patients, if any, with respiratory tract infections and number of deaths among those originally excluded from the analysis.

Besides the general eligibility rule adopted in this meta-analysis - that is, randomised treatment allocation-the special features of four studies required ad hoc decisions. One study, ${ }^{6}$ though not randomised formally, was included as it used a strictly double blind scheme. Three randomised trials were excluded for the following reasons. Direct inquiry with the principal investigator in a trial containing 204 patients (102 treated and 102 controls, with 92 respiratory tract infections and 158 deaths $)^{7}$ showed that a consecutive non-randomised treatment allocation was used despite the study being indexed as randomised. Two other trials (containing 114 patients $^{8}$ (56 treated and 58 controls, with nine respiratory tract infections and five deaths) and 104 patients $^{9}$ (52 treated and 52 controls, with 18 respiratory tract infections and 48 deaths)) were excluded because they were concerned with having oesophageal resection ${ }^{8}$ or with acute fulminant hepatic failure.

The results presented here are thus based on 22 independent randomised controlled trials. In the tables and figures, however, 23 studies are shown because the three arm trial ${ }^{10}$ was split into two parts and contrasted the effects of two different treatments, but with the same control group. Only 22 trials contributed data on the effect of selective decontamination of the digestive tract on respiratory tract infections because one study ${ }^{11}$ considered only septicaemia; mortality data were available from all 23 studies. Table I shows the general characteristics of the trials.

\section{STATISTICAL METHODS}

Crude proportions of respiratory tract infections and total mortality were assessed as treatment end points. Intention to treat analysis was carried out on the study populations, randomly assigned to control or selective decontamination. Odds ratios of each outcome in each trial were computed with the Mantel-Haenszel-Peto method. ${ }^{12}$ Odds ratios and pooled odds ratios together with their 95\% confidence intervals are reported separately for respiratory tract infections and deaths.

TABLE I-General characteristics of randomised clinical trials included in meta-analysis

\begin{tabular}{|c|c|c|c|c|c|c|c|c|}
\hline Reference & Inclusion criteria & $\begin{array}{c}\text { Mean } \\
\text { age } \\
\text { (years) }\end{array}$ & $\begin{array}{l}\text { Mean } \\
\text { severity } \\
\text { score }\end{array}$ & $\begin{array}{c}\% \\
\text { Trauma } \\
\text { patients }\end{array}$ & $\begin{array}{c}\% \\
\text { Survical } \\
\text { patients }\end{array}$ & $\begin{array}{c}\% \\
\text { Medical } \\
\text { patients }\end{array}$ & $\begin{array}{l}\text { Whether } \\
\text { blinded }\end{array}$ & Type of treatment \\
\hline Rocha et al ${ }^{20}$ & $\begin{array}{l}\text { Patients with }>3 \text { days of mechanical } \\
\text { ventilation and }>5 \text { days of stay }\end{array}$ & $43 \cdot 5$ & $15 \cdot 5 t$ & 79 & 0 & 21 & Yes & $\begin{array}{l}\text { Topical: polymyxin-tobramycin-amphotericin } \mathrm{B} \text {. } \\
\text { systemic: cefotaxime }\end{array}$ \\
\hline Pugin $e t a l^{26}$ & $\begin{array}{l}\text { Patients at risk of ventilator associated } \\
\text { pneumonia }\end{array}$ & $45 \cdot 5$ & $15 \cdot 3 t$ & 52 & 12 & 36 & Yes & Topical: polymyxin-neomycin-vancomycin \\
\hline Korinek et a $l^{\natural}$ & $\begin{array}{l}\text { Patients intubated from less than } 24 \text { hours } \\
\text { and having at least } 5 \text { days of stay }\end{array}$ & $45 \cdot 0$ & $10.9 \ddagger$ & 50 & 50 & 0 & Yes & Topical: polymyxin-tobramycin-amphotericin B. \\
\hline Rodriguez-Roldan $e t a l^{34}$ & $\begin{array}{l}\text { Patients mechanically ventillated for } \geqslant 72 \\
\text { hours }\end{array}$ & $51 \cdot 3$ & $17 \cdot 0 t$ & 48 & 16 & 36 & Yes & Topical: polymyxin-tobramycin-amphotericin B \\
\hline Palomar et als & $\begin{array}{l}\text { Non-infected, non-treated patients } \\
\text { ventilated for }>4 \text { days }\end{array}$ & $45 \cdot 5$ & $16 \cdot 6 t$ & 45 & 17 & 38 & No & $\begin{array}{l}\text { Topical: polymyxin-tobramycin-amphotericin } B \text {. } \\
\text { systemic: cefotaxime }\end{array}$ \\
\hline Godard et al & All patients & $49 \cdot 0$ & $13.9 \ddagger$ & 41 & 28 & 31 & Yes & Topical: polymyxin-tobramycin \\
\hline Blair et $a l^{2}$ & Patients in intensive care unit for $>48$ hours & $47 \cdot 9$ & $14 \cdot 0 t$ & 40 & 45 & 15 & No & $\begin{array}{l}\text { Topical: polymyxin-tobramycin-amphotericin } B \text {. } \\
\text { systemic: cefotaxime }\end{array}$ \\
\hline Aerdts et $a^{21}$ & $\begin{array}{l}\text { Patients expected to be ventilated for } \geqslant 5 \\
\text { days }\end{array}$ & $46 \cdot 7$ & $22 \cdot 3 t$ & 34 & 25 & 41 & No & $\begin{array}{l}\text { Topical: polymyxin-norfloxacin-amphotericin } B \text {. } \\
\text { systemic: cefotaxime }\end{array}$ \\
\hline Unertl et a $P^{8}$ & $\begin{array}{l}\text { Patients intubated within } 24 \text { hours after } \\
\text { acute event and expected to be ventilated } \\
\text { for }>6 \text { days }\end{array}$ & $49 \cdot 4$ & $12 \cdot 5 \ddagger$ & 33 & 15 & 52 & No & Topical: polymyxin-gentamicin-amphotericin B \\
\hline Kerver et $a l^{3}$ & Patients requiring intensive care for $>5$ days & $55 \cdot 6$ & $14 \cdot 8 \dagger$ & 28 & 60 & 12 & No & $\begin{array}{l}\text { Topical: polymyxin-tobramycin-amphotericin } B \text {. } \\
\text { systemic: cefotaxime }\end{array}$ \\
\hline Hammond et $a^{32}$ & $\begin{array}{l}\text { Patients expected to require intubation for } \\
>48 \text { hours and to remain in intensive care } \\
\text { for } \geqslant 5 \text { days }\end{array}$ & $43 \cdot 3$ & $14 \cdot 7 \dagger$ & 27 & 14 & 59 & Yes & $\begin{array}{l}\text { Topical: polymyxin-tobramycin-amphotericin B. } \\
\text { systemic: cefotaxime. (Both arms) }\end{array}$ \\
\hline Verhaegen $1^{10}$ & $\begin{array}{l}\text { Patients expected to be ventilated for }>48 \\
\text { hours }\end{array}$ & $55 \cdot 8$ & $18 \cdot 3 \dagger$ & 24 & 66 & 10 & No & $\begin{array}{l}\text { Topical: polymyxin-tobramycin-amphotericin } B \text {. } \\
\text { systemic: cefotaxime }\end{array}$ \\
\hline Ferrer $e t a \beta^{\beta s}$ & Ventilated patients & $61 \cdot 0$ & $12 \cdot 4 \ddagger$ & 23 & 13 & 64 & Yes & $\begin{array}{l}\text { Topical: polymyxin-tobramycin-amphotericin B. } \\
\text { systemic: cefotaxime. (Both arms) }\end{array}$ \\
\hline Verhaegen $2^{10}$ & $\begin{array}{l}\text { Patients expected to be ventilated for }>48 \\
\text { hours }\end{array}$ & $56 \cdot 3$ & $17 \cdot 9 \dagger$ & 22 & 68 & 10 & No & $\begin{array}{l}\text { Topical: ofloxacin-amphotericin B. } \\
\text { systemic: ofloxacin }\end{array}$ \\
\hline Jacobs et al $l^{4}$ & $\begin{array}{l}\text { Patients expected to remain in intensive care } \\
\text { for }>3 \text { days }\end{array}$ & $51 \cdot 5$ & $17 \cdot 6+$ & 18 & 57 & 25 & No & $\begin{array}{l}\text { Topical: polymyxin-tobramycin-amphotericin } \mathbf{B} \text {. } \\
\text { systemic: cefotaxime }\end{array}$ \\
\hline Sanchez-Garcia ${ }^{30}$ & Patients intubated for $>48$ hours & $54 \cdot 5$ & $26 \cdot 0 t$ & 17 & 12 & 71 & Yes & $\begin{array}{l}\text { Topical: polymyxin-gentamicin-amphotericin } \mathrm{B} \text {. } \\
\text { systemic: ceftriaxone }\end{array}$ \\
\hline Cockerill et $a^{p \hbar \star}$ & $\begin{array}{l}\text { Patients expected to remain in intensive care } \\
\text { for } \geqslant 3 \text { days }\end{array}$ & $65 \cdot 0$ & $18 \cdot 4 \dagger$ & 15 & 48 & 17 & No & $\begin{array}{l}\text { Topical: polymyxin-gentamicin-nystatin. } \\
\text { systemic: cefotaxime }\end{array}$ \\
\hline Gastinne et $a l^{s}$ & $\begin{array}{l}\text { Patients ventilated with intubation } \\
\text { performed }<48 \text { hours before } \\
\text { randomisation }\end{array}$ & $55 \cdot 0$ & $13 \cdot 5 \ddagger$ & 15 & 13 & 72 & Yes & Topical: polymyxin-tobramycin-amphotericin B \\
\hline Ulrich et $a^{z}$ & $\begin{array}{l}\text { Patients expected to remain in intensive care } \\
\text { for }>5 \text { days }\end{array}$ & $62 \cdot 0$ & $12 \cdot 0 \ddagger$ & 14 & 56 & 30 & No & $\begin{array}{l}\text { Topical: polymyxin-norfloxacin-amphotericin } \mathrm{B} \text {. } \\
\text { systemic: trimethoprim }\end{array}$ \\
\hline Winter et $a^{p 9}$ & $\begin{array}{l}\text { Patients expected to remain in intensive care } \\
\text { for }>48 \text { hours }\end{array}$ & $59 \cdot 2$ & $14 \cdot 0 \dagger$ & 12 & 39 & 49 & No & $\begin{array}{l}\text { Topical: polymyxin-tobramycin-amphotericin } B \text {. } \\
\text { systemic: ceftazidime }\end{array}$ \\
\hline Cerra $e t a l^{3}$ & $\begin{array}{l}\text { Patients within } 48 \text { hours of acute event and } \\
\text { expected to remain in intensive care for } \\
>5 \text { days }\end{array}$ & $63 \cdot 5$ & Not done & 4 & 96 & 0 & Yes & Topical: norfloxacin-nystatin \\
\hline Brun-Buisson $e t a l^{1}$ & $\begin{array}{l}\text { Patients with unit stay of }>2 \text { days and } \\
\text { severity score of }>2\end{array}$ & $59 \cdot 0$ & $11 \cdot 4 \ddagger$ & 2 & 19 & 79 & No & Topical: polymyxin-neomycin-nalidixic acid \\
\hline Gaussorgues $e t a l^{11}$ & Patients mechanically ventilated & $57 \cdot 0$ & $17 \cdot 5 \ddagger$ & 0 & 16 & 84 & No & $\begin{array}{l}\text { Topical: polymyxin-gentamicin-amphotericin B. } \\
\text { vancomycin }\end{array}$ \\
\hline
\end{tabular}




\begin{tabular}{|c|c|c|c|c|c|c|c|}
\hline \multirow[b]{2}{*}{ Reference } & \multirow[b]{2}{*}{$\begin{array}{l}\text { Whether } \\
\text { protected } \\
\text { catheter }\end{array}$} & \multirow{2}{*}{$\begin{array}{l}\text { Incidence of } \\
\text { infection } \\
\text { among } \\
\text { controls (\%) }\end{array}$} & \multicolumn{2}{|c|}{$\begin{array}{c}\text { Patients given active } \\
\text { treatment }\end{array}$} & \multicolumn{2}{|c|}{ Controls } & \multirow[b]{2}{*}{$\begin{array}{l}\text { Odds ratio ( } 95 \% \\
\text { confidence interval) }\end{array}$} \\
\hline & & & $\begin{array}{l}\text { No in } \\
\text { group }\end{array}$ & $\begin{array}{r}\text { No with } \\
\text { infection }\end{array}$ & $\begin{array}{l}\text { No in } \\
\text { group }\end{array}$ & $\begin{array}{l}\text { No with } \\
\text { infection }\end{array}$ & \\
\hline Rocha et ato & Yes & 46 & 47 & 7 & 54 & 25 & $0.24(0.1$ to 0.55$)$ \\
\hline Pugin et al ${ }^{26}$ & Yes & 59 & 38 & 4 & 41 & 24 & $0.13(0.05$ to 0.32$)$ \\
\hline Korinek et al ${ }^{19}$ & Yes & 39 & 96 & 20 & 95 & 37 & $0.42(0.23$ to 0.78$)$ \\
\hline Rodriguez-Roldan ${ }^{34}$ & Yes & 65 & 14 & 1 & 17 & 11 & $0.01(0.02$ to 0.40$)$ \\
\hline Palomar et a $P^{25}$ & Yes & 53 & 48 & 10 & 49 & 26 & $0.25(0.11$ to 0.58$)$ \\
\hline Godard et at & Yes & 15 & 101 & 2 & 84 & 13 & $0.17(0.06$ to 0.48$)$ \\
\hline Blair et a $P^{22}$ & No & 22 & 161 & 12 & 170 & 38 & $0.31(0.17$ to 0.57$)$ \\
\hline Aerdts et a $P^{1}$ & No & 48 & 28 & 1 & 60 & 29 & $0.14(0.05$ to 0.36$)$ \\
\hline Unertl et af ${ }^{8}$ & No & 45 & 19 & $i$ & 20 & 9 & $0.13(0.03$ to 0.54$)$ \\
\hline Kerver et $a p^{33}$ & No & 94 & 49 & 22 & 47 & 44 & $0.11(0.04$ to 0.25$)$ \\
\hline Hammond et $a b^{32}$ & No & 19 & 162 & 25 & 160 & 30 & $0.79(0.44$ to 0.41$)$ \\
\hline Verhaegen $1^{10}$ & No & 22 & 200 & 31 & 185 & 40 & $0.67(0.40$ to 1.12$)$ \\
\hline Ferrer et $a l^{35}$ & Yes & 24 & 39 & 9 & 41 & 10 & $0.93(0.33$ to 2.59$)$ \\
\hline Verhaegen $2^{10}$ & No & 22 & 193 & 22 & 185 & 40 & $0.48(0.28$ to 0.82$)$ \\
\hline Jacobs et a ${ }^{p A}$ & No & 9 & 45 & 0 & 46 & 4 & $0.13(0.02$ to 0.95$)$ \\
\hline Sanchez-Garcia ${ }^{30}$ & No & 43 & 131 & 31 & 140 & 60 & $0.42(0.26$ to 0.70$)$ \\
\hline Cockerill et $a l^{17}$ & No & 16 & 75 & 4 & 75 & 12 & $0.33(0.12$ to 0.92$)$ \\
\hline Gastrinne et $a l^{18}$ & Yes & 19 & 220 & 31 & 225 & 42 & $0.72(0.43$ to 1.18$)$ \\
\hline Ulrich et $a P^{27}$ & No & 46 & 55 & 7 & 57 & 26 & $0.21(0.09$ to 0.47$)$ \\
\hline Winter et a $p^{29}$ & No & 18 & 91 & 3 & 92 & 17 & $0.21(0.08$ to 0.54$)$ \\
\hline Cerra et a $f^{23}$ & No & 100 & 25 & 14 & 23 & 23 & $0.09(0.02$ to 0.33$)$ \\
\hline Brun-Buisson et al $l^{11}$ & Yes & 9 & 65 & 3 & 68 & 6 & $0.52(0.13$ to 1.99$)$ \\
\hline
\end{tabular}

We also used the random effect model as proposed by DerSimonian and Laird, ${ }^{13}$ where the variable of interest in each study is the difference in event rates between the treated and control groups. As the two methods gave similar $\mathrm{p}$ values for the difference between treated and control groups only the results of analysis by the Mantel-Haenszel-Peto method are given.

Heterogeneity between trials was tested by $\chi^{2}$ test. However, such a test of heterogeneity among many different trials has limited value for reasons specific to this meta-analysis and for more general reasons. Firstly, in this series a substantial quantitative variation in treatment effect, possibly due to differences in patient mix and severity of disease, was evident. Furthermore, whatever results are obtained this test provides limited reassurance, given that it has low power and is dominated by the unstable contributions from the smaller studies that might obscure any real heterogeneity among the larger studies.

In order to make our results more intelligible and illustrate the clinical relevance of the treatment we computed the number of intensive care unit patients who would need to be treated in order to prevent one respiratory tract infection and one death according to the method proposed by Laupacis et al. ${ }^{14}$ The calculation was based on the median rates of respiratory tract infection and death in untreated controls $(29 \%$ in both instances) and the common odds ratio for all trials. The ranges of these estimates were computed with reference to the values of the upper and lower $95 \%$ confidence intervals. Sensitivity analyses of these estimates were also carried out to see how the number of patients needed to be treated varied at different levels of baseline risk of infection and mortality while the estimated odds of infection and mortality reduction were being held constant.

A series of pre-specified subgroup analyses was also carried out. To analyse the effect of selective decontamination on respiratory tract infections trials were grouped according to (a) type of diagnostic procedures (use of quantitative microbiology on distal protected specimen $v$ other sampling techniques); (b) blinding of patients and doctors to allocated treatment (yes or no); (c) type of selective decontamination used (topical regimen $v$ topical plus systemic); (d) quality of randomisation procedures (that is, efforts to blind doctors to the treatment in the next case-for example, by using telephone randomisation or sealed envelopes $v$ other mechanisms, such as an open randomisation list, date of birth, and odd and even numbers).
For the analysis of overall mortality trials were grouped according to $(a)$ blinding of patients and doctors to allocated treatment (yes or no); (b) type of selective decontamination used (topical regimen $v$ topical plus systemic); (c) quality of randomisation procedures (as above). In the relevant subgroup analysis trials in which a systemic antibiotic was delivered to all patients (that is, to treated patients and controls) were included in the topical group only.

An estimate of the magnitude of the relation between respiratory tract infections and mortality was attempted by means of a weighted multiple regression analysis. The weights were constructed in such a way that study arms with more information contributed more to the regression. ${ }^{15}$ The slope of the weighted linear regression coefficient fit to these data is the regression coefficient $\beta$ relating $1 \mathrm{n}$ odds of respiratory tract infections to $1 \mathrm{n}$ odds of death. This analysis did not compare treatment arms of different trials, and thus estimates based on comparisons within the same clinical trials only.

In all tables and figures trials are presented in decreasing order of proportions of trauma patients enrolled: there is widespread belief that this group is likely to benefit most from selective decontamination. ${ }^{16}$

\section{Results}

\section{STUDY POPULATION}

Studies reported between January 1984 and June 1992 included 4142 patients. By June 1993, 18 studies had been published, one was accepted for publication, and three were unpublished. Methods of randomisation were as follows: 15 studies used blind randomisation (four by telephone, ${ }^{17-20} 11$ with sealed envelopes ${ }^{1021-30}$ ); six used methods such as odd and even numbers ${ }^{1131-35}$; and one used a double blind allocation method. ${ }^{6}$ Ten used a double blind design (table I), and nine used a protected catheter to distinguish pneumonia from respiratory tract infections (table II).

\section{PATIENT MIX AND TREATMENTS}

All trials included unselected general patients with an expected stay in intensive care of five days or more or a projected need for mechanical ventilation for $\mathbf{4 8}$ hours or more (table I). Trial populations differed in age (mean range 43-65 years), size (range 31-445 members), severity scores, and proportions of medical (range $0-84 \%$ ), surgical $(0-96 \%)$, and trauma $(0-79 \%)$ patients. Timing of mortality assessment was also variable, most trials referring to intensive care unit mortality. 
Nineteen trials had two arms, the control being a placebo or non-treatment arm. Three studies had three arms. One study ${ }^{21}$ had one treated and two control groups with different policies for treating infection, and two studies ${ }^{1025}$ had one control and two different treatment groups. Only two arms (selective decontamination and untreated control in the study of Palomar $\left.e t a^{2 s}\right)$ were considered and the sucralfate treated arm was excluded. The study by Verhaegen ${ }^{10}$ was split into two parts, a different selective decontamination regimen being tested in each but the same control group being used. In all tables and figures the total number of trials is 23 , this last trial being listed as Verhaegen $1^{10}$ (comparing polymyxin, tobramycin, and amphotericin $B$ plus systemic cefotaxime $v$ no treatment) and Verhaegen $2^{10}$ (comparing ofloxacin plus amphotericin B $v$ no treatment) (table I). There was great variability among the antibiotic protocols used in different studies. Only three regimens were tested in more than one trial, one regimen (polymyxin, tobramycin, amphotericin B, and systemic cefotaxime) being tested in six of the 23 studies.

\section{EFFECTS ON RESPIRATORY TRACT INFECTIONS}

The protective effect of selective decontamination on respiratory tract infections was by far the most common end point. The odds ratio was lower than 1.0 in all trials and reached conventional statistical significance $(p<0.05)$ in 17 of 22 . Analysis of the effect of selective decontamination on respiratory tract infections was based on 3836 patients and 826 events (in 260 treated patients and 566 controls) and suggested a significant $64 \%$ reduction in the relative odds of developing an infection (odds ratio $0.37 ; 95 \%$ confidence interval 0.31 to 0.43 ) when patients treated by selective decontamination were compared with untreated controls (fig 1). This effect was consistent across all subgroups (fig 2). The number of patients who would need to be treated to prevent one respiratory tract infection was six (range five to nine), and these estimates seemed to be fairly stable for baseline

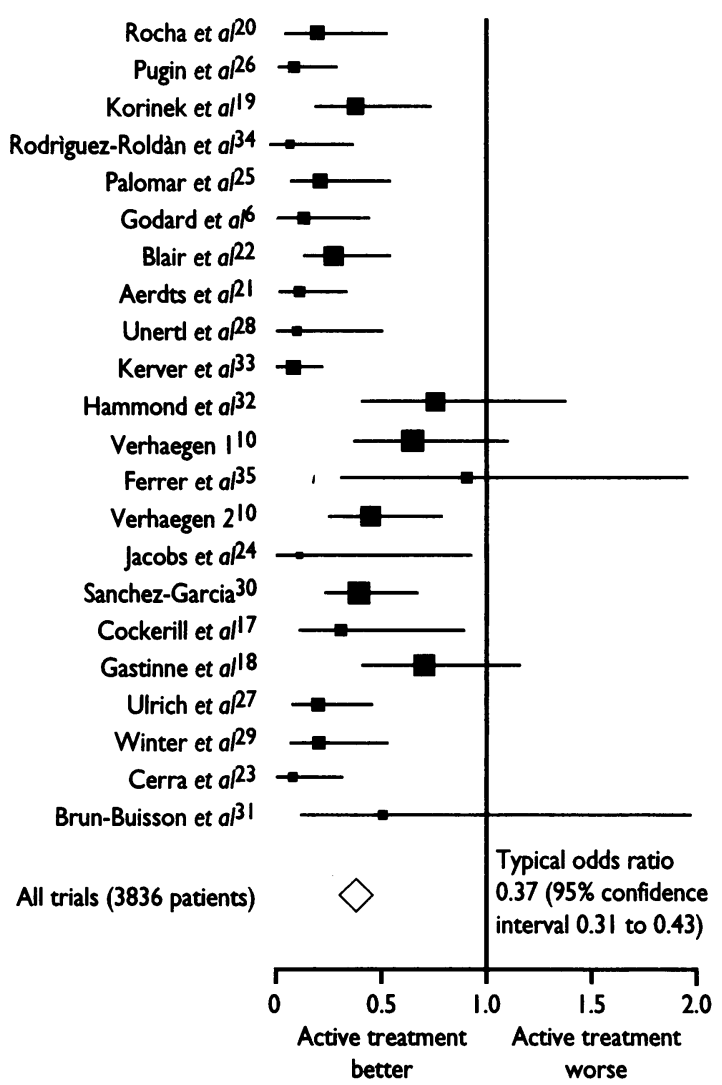

FIG 1-Overall effect of selective decontamination of the digestive tract on respiratory tract infections

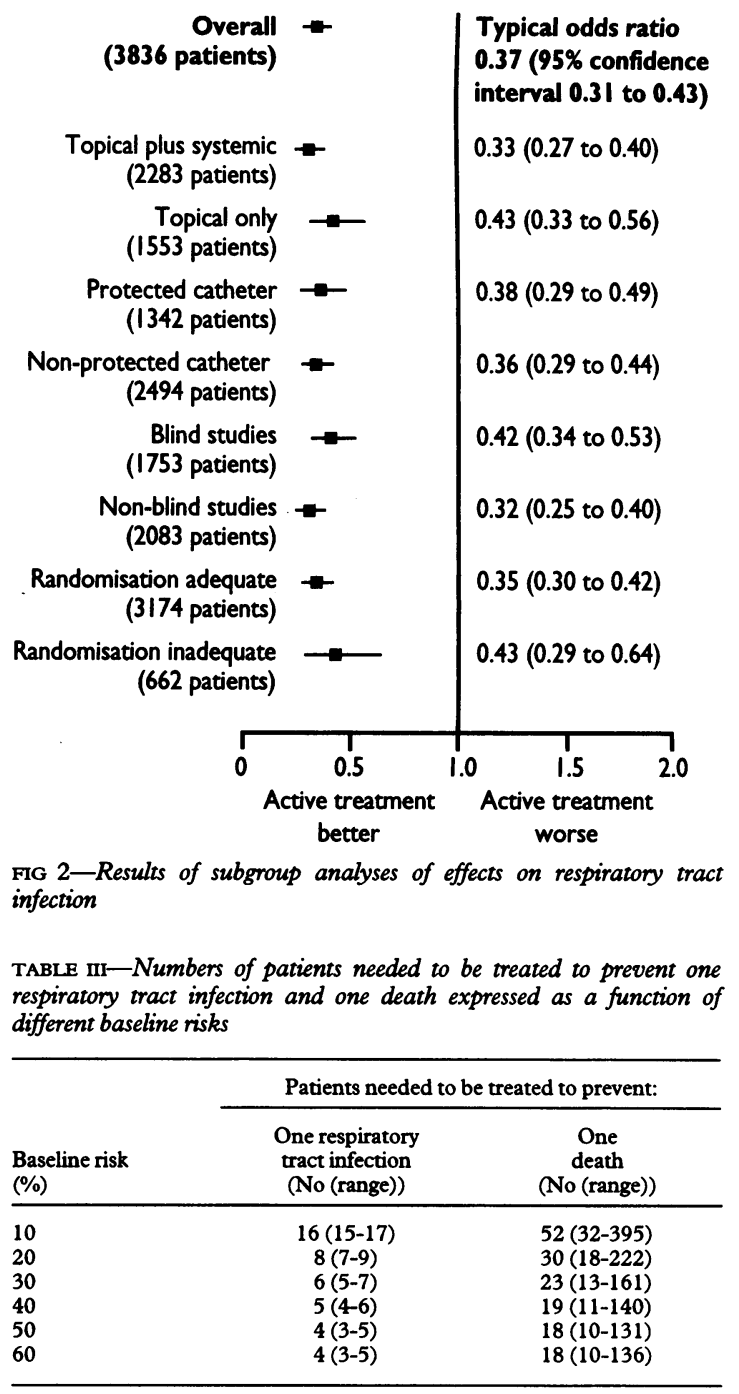

values of respiratory tract infections ranging from $20 \%$ to $60 \%$ (table III). As expected, owing to the large variation in treatment across trials the value of the heterogeneity test for the overall comparison was significant $\left(X^{2}=61.5, \mathrm{df}=21 ; \mathrm{p}<0.001\right)$.

\section{EFFECT ON OVERALI MORTALITY}

Pooled analysis of available trials yielded less clear cut results (table IV). The odds ratio was lower than 1.0 in 14 trials and reached borderline significance $(p=0.006)$ in three. ${ }^{2024} 27$ No trial showed a significant or borderline harmful effect of selective decontamination. The overall mortality analysis, based on 4142 patients and 1160 deaths (553 among treated patients, 607 among controls), showed no significant difference in the relative odds of death when patients treated by selective decontamination were compared with untreated controls (odds ratio $0.90 ; 95 \%$ confidence interval 0.79 to 1.04 ) (fig 3). Results of subgroup analysis (fig 4) of 2450 patients suggested that for mortality the most promising results came from trials in which the combined topical and systemic treatment was used. In this subgroup a significant reduction of $20 \%$ in the odds of death occurred (odds ratio 0.80 ; 0.67 to 0.97 ), corresponding to 23 patients needing treatment to prevent one death (range 13-139). These estimates were fairly stable for baseline values of mortality ranging from $30 \%$ to $60 \%$ (table III).

No differences emerged with the design of the study (that is, double blind or not) or the quality of the randomisation process. The test for heterogeneity between odds ratios for the overall mortality analysis yielded a non-significant result $\left(\chi^{2}=17 \cdot 9, \mathrm{df}=22\right.$; $\mathrm{p}=0.7)$. 


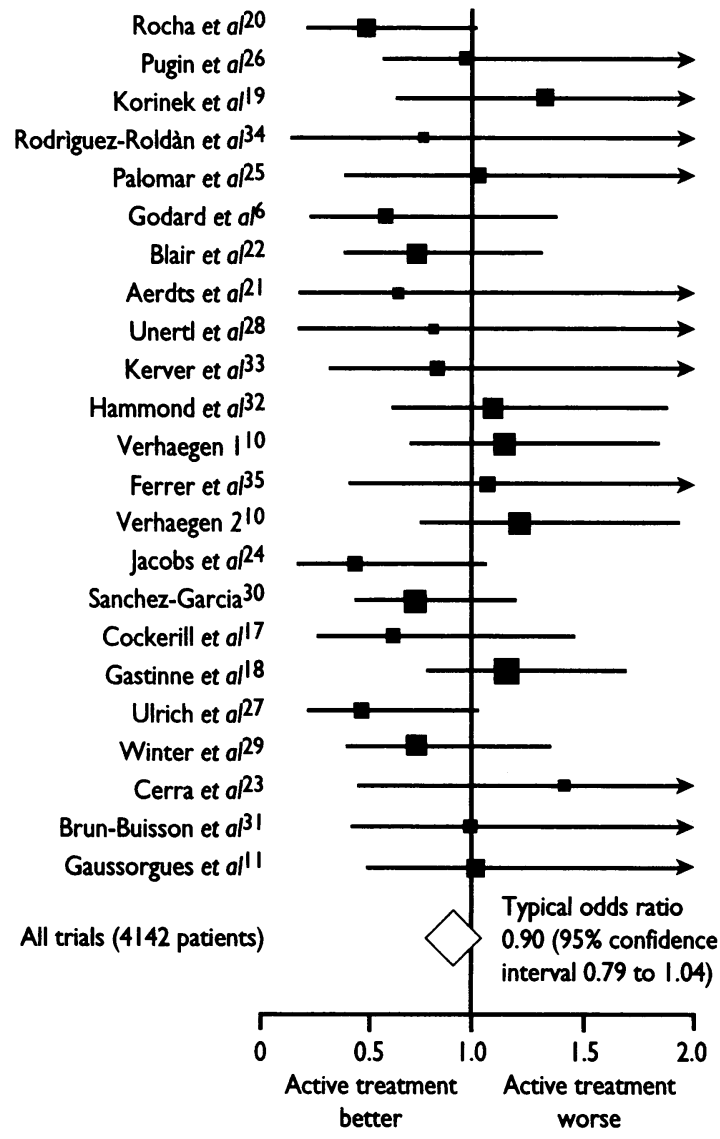

FIG 3-Overall effect of selective decontamination of the digestive tract on mortality

\section{SENSITIVITY ANALYSIS}

Publication bias is unlikely to have affected the validity of our conclusions for at least three reasons: (a) our search detected most if not all published trials and also some unpublished studies; $(b)$ most trial results were not statistically significant on their own, so making systematic result dependent publication extremely unlikely; (c) even if one or more negative studies remained undetected we estimate that they would need to have contained at least 20000 and 2000 patients to change our conclusions on respiratory tract infections and morality respectively. ${ }^{36}$ Different decisions about eligibility would not have changed our results: had we included the three trials ${ }^{7-9}$ excluded by design from this meta-analysis there would have been no major effect on the results. The overall odds ratio

TABLE IV-Mortality results of randomised clinical trials included in meta-analysis

\begin{tabular}{|c|c|c|c|c|c|c|}
\hline \multirow[b]{2}{*}{ Reference } & \multirow[b]{2}{*}{$\begin{array}{l}\% \text { Mortality } \\
\text { in controls }\end{array}$} & \multicolumn{2}{|c|}{$\begin{array}{c}\text { Patients given active } \\
\text { treatment }\end{array}$} & \multicolumn{2}{|c|}{ Controls } & \multirow[b]{2}{*}{$\begin{array}{l}\text { Odds ratio ( } 95 \% \\
\text { confidence interval) }\end{array}$} \\
\hline & & $\begin{array}{l}\text { No in } \\
\text { group }\end{array}$ & $\begin{array}{l}\text { No of } \\
\text { deaths }\end{array}$ & $\begin{array}{l}\text { No in } \\
\text { group }\end{array}$ & $\begin{array}{l}\text { No of } \\
\text { deaths }\end{array}$ & \\
\hline Rocha et al $P^{20}$ & 52 & 74 & 27 & 77 & 40 & $0.54(0.28$ to 1.02$)$ \\
\hline Pugin et a $P^{6}$ & 27 & 38 & 10 & 41 & 11 & $0.97(0.36$ to 2.63$)$ \\
\hline Korinek et al ${ }^{19}$ & 18 & 96 & 22 & 95 & 17 & $1.36(0.67$ to 2.74$)$ \\
\hline Rodriguez-Roldan $^{34}$ & 41 & 14 & 5 & 17 & 7 & $0.80(0.19$ to 3.34$)$ \\
\hline Palomar et af ${ }^{25}$ & 29 & 48 & 14 & 49 & 14 & $1.03(0.43$ to 2.47$)$ \\
\hline Godard et at & 18 & 101 & 12 & 84 & 15 & $0.62(0.27$ to 1.41$)$ \\
\hline Blair et a $\mathbb{P}^{2}$ & 19 & 161 & 24 & 170 & 32 & $0.76(0.43$ to 1.34$)$ \\
\hline Aerdts et af1 & 20 & 28 & 4 & 60 & 12 & $0.68(0.22$ to 2.17$)$ \\
\hline Unertl et af ${ }^{88}$ & 30 & 19 & 5 & 20 & 6 & $0.84(0.21$ to 3.32$)$ \\
\hline Kerver et a $P^{33}$ & 32 & 49 & 14 & 47 & 15 & $0.85(0.36$ to 2.03$)$ \\
\hline Hammond et $a b^{2}$ & 19 & 162 & 34 & 160 & 31 & $1.10(0.64$ to 1.90$)$ \\
\hline Verhaegen $1^{10}$ & 18 & 220 & 45 & 220 & 40 & $1.16(0.72$ to 1.86$)$ \\
\hline Ferrer et $a l^{35}$ & 28 & 51 & 15 & 50 & 14 & $1.07(0.45$ to 2.52$)$ \\
\hline Verhaegen $2^{10}$ & 18 & 220 & 47 & 220 & 40 & $1.22(0.76$ to 1.95$)$ \\
\hline Jacobs et al ${ }^{P_{4}^{4}}$ & 50 & 45 & 14 & 46 & 23 & $0.46(0.20$ to 1.06$)$ \\
\hline Sanchez-Garcia ${ }^{30}$ & 46 & 131 & 51 & 140 & 65 & $0.74(0.46$ to 1.19$)$ \\
\hline Cockerill et $\mathrm{al}^{17}$ & 21 & 75 & 11 & 75 & 16 & $0.64(0.28$ to 1.46$)$ \\
\hline Gastinne et $a l^{18}$ & 36 & 220 & 88 & 225 & 82 & $1.16(0.79$ to 1.70$)$ \\
\hline Ulrich et af ${ }^{27}$ & 58 & 55 & 22 & 57 & 33 & $0.49(0.24$ to 1.03$)$ \\
\hline Winter et a $p^{p g}$ & 43 & 91 & 33 & 92 & 40 & $0.74(0.41$ to 1.34$)$ \\
\hline Cerra et a $p^{3}$ & 43 & 25 & 13 & 23 & 10 & $1.40(0.46$ to 4.29$)$ \\
\hline Brun-Buisson et a $\vec{l}^{11}$ & 22 & 65 & 14 & 68 & 15 & $0.97(0.43$ to 2.20$)$ \\
\hline Gaussorgues $e t a l^{1}$ & 49 & 59 & 29 & 59 & 29 & $1.00(0.49$ to 2.05$)$ \\
\hline
\end{tabular}

for respiratory tract infections would have been 0.37 (95\% confidence interval 0.32 to 0.43 ) and for overall mortality $0.84(0.74$ to 0.97$)$. Similarly, results for overall and subgroup analyses obtained with the DerSimonian-Laird method ${ }^{13}$ gave similar $p$ values for the difference between treated and control groups in terms of both infections and mortality (results available on request).

\section{Discussion}

\section{CONTRIBUTION OF THIS META-ANALYSIS}

The concept of selective decontamination, first applied by Stoutenbeek et al to patients in intensive care units, ${ }^{1}$ has received widespread attention. In some instances interest was created by the initial results of reduction of infection in trauma patients. ${ }^{16}$ Others were concerned that this unusual use of antimicrobials might select resistant micro-organisms. ${ }^{37}$ In fact, the original selective decontamination concept of preventive use of oral non-absorbable antimicrobials combined with systemic cefotaxime for at least four days represented a profound shift in traditional infection control policy based on restricted use of narrow spectrum antibiotics only if infection, not colonisation, occurred. ${ }^{38}$

Many studies have assessed the value of selective decontamination but most suffer from conceptual and methodological problems. ${ }^{34}$ The ideal study should include $(a)$ enrolment of a clinically homogeneous group of patients, $(b)$ the use of a well defined treatment regimen, (c) stringent criteria for defining infections, and $(d)$ compliance with accepted principles of study design (that is, double blind schemes of allocation and proper diagnostic measurements). As shown in tables I and II many of the studies we evaluated lacked one or more of these characteristics. Moreover, variations in patient mix both within and between studies prevented scrutiny of specific subgroups who may particularly benefit from treatment.

There is little doubt that selective decontamination as an overall treatment strategy reduces respiratory tract infections, by far the most common and serious infections in intensive care units. However, the variation in prescribed antibiotics and patient mix in individual studies was so large that it may be difficult for a clinician to decide what to do. Nevertheless, we cannot ignore the remarkable consistency in the direction of treatment effect, which held true regardless of the type of treatment, criteria for outcome ascertainment, and study design (fig 2).

The question now is whether selective decontamination affects mortality in a way that is both clinically

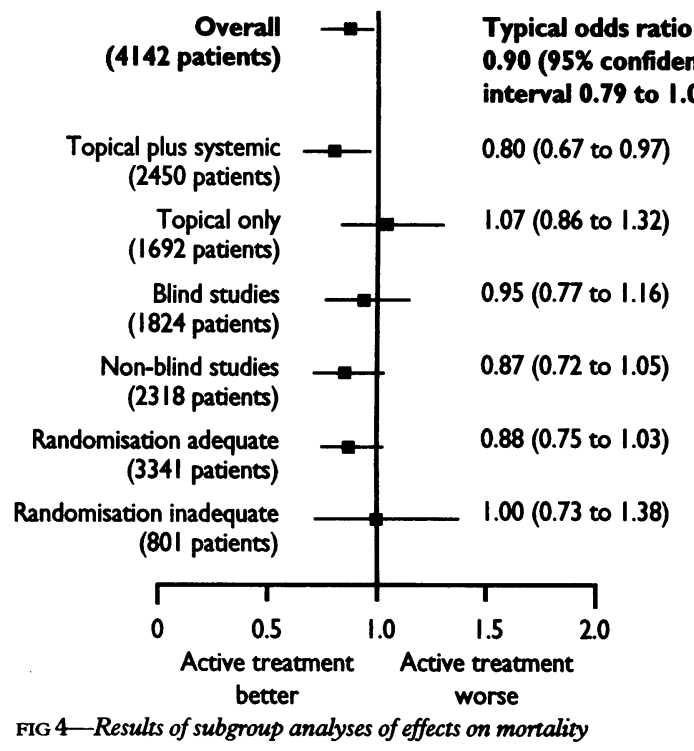


relevant for physicians and worth while for public health. Our meta-analysis provides new insights on the effect of selective decontamination on mortality and represents the reference point against which any claim of efficacy should be judged. Thus it allows us to set realistic expectations of the effect of selective decontamination on mortality when it is applied to heterogeneous patient populations such as those studied so far.

We now know that the mean frequency of respiratory tract infections in selective decontamination trials is around $30 \%$, that selective decontamination can reduce respiratory tract infections by around $60 \%$, and that baseline mortality among untreated patients in selective decontamination trials is between $30 \%$ and $35 \%$. Given these figures, an estimate of likely benefit of selective decontamination might be around 10-20\% and could reliably be detected (with conventional levels of type I and type II errors) only if at least 2000 patients were randomised between selective decontamination and no treatment or placebo groups. This is important because two reports of individual trials enrolling a few hundred patients ${ }^{1832}$ and the first metaanalysis ${ }^{2}$ based on only 400 patients concluded with unjustified confidence that selective decontamination is unlikely to affect mortality. It is also of interest that with about 2450 patients in the topical plus systemic subgroup we found a reduction in mortality of this magnitude.

The infection-mortality relation is important. According to our multiple regression analysis there is a significant association between respiratory tract infection and mortality (overall estimate $\beta=0.141$ $(\mathrm{SE}=0.041) ; \mathrm{p}=0.003)$. However, the predicted absolute reduction in death rates given an overall relative reduction in odds of respiratory tract infection of $63 \%$ (that is, the value of the common reduction in odds of infections) ranges from $2 \%$ to $3 \%$ and the predicted relative reduction in odds of death ranges from $5 \%$ to $10 \%$ (table $\mathrm{V}$ ). The weak association between reduction of infection and reduction in mortality will not surprise those who believe that selective decontamination is not worth while; in their view most intensive care unit patients die with but not of infection. This may be the case, especially for patients classified as "medical," and might explain the relative dissonance between the effect of selective decontamination on infection and mortality in some studies. However, those who believe that selective decontamination can be beneficial will assume that our effect detected from within a mix of heterogeneous studies will be greater when applied to appropriate patients, thus avoiding the dilution of treatment likely to have occurred in these studies.

Results of subgroup analyses, even if planned beforehand, should always be interpreted with caution. With the exception of the one comparing trials in which the combined topical and systemic treatment was used with that where only the topical regimen was administered other subgroup analyses did not provide any meaningful insight. On the contrary, they tended to make the interpretation more complicated. When we grouped trials on the basis of different proportions

TABLE V-Estimates of predicted for different baseline death rates, given $63 \%$ reduction in odds of respiratory tract infection attributable to selective decontamination of the digestive tract according to metaanalysis

\begin{tabular}{lcc}
\hline $\begin{array}{l}\text { Baseline death rate } \\
(\%)\end{array}$ & $\begin{array}{c}\text { Predicted death rate } \\
(\%)\end{array}$ & $\begin{array}{c}90 \% \text { Confidence interval } \\
\text { (\%) }\end{array}$ \\
\hline 60 & 57 & 55 to 58 \\
50 & 47 & 45 to 48 \\
40 & 37 & 35 to 38 \\
30 & 27 & 26 to 29 \\
20 & 18 & 17 to 19 \\
10 & 9 & 8 to 10 \\
\hline
\end{tabular}

of medical, surgical, and trauma patients we found inconsistent and somewhat conflicting results which depended on the cut off points chosen. As our unit of analysis was the trials (not the patients) it was impossible to separate the relative contribution of treatment and patient mix to the overall effect of selective decontamination. Such a limitation can be overcome only by a meta-analysis based on individual patient data. ${ }^{39}$ This might enable a group of patients who would benefit from selective decontamination to be identified. For example, in patients who were not infected when entered into the trials (that is, trauma patients) the parenteral antibiotic component might have prevented primary endogenous infections. If so, this together with the topical antimicrobials may have lowered the risk of secondary endogenous infections known to be responsible for substantial mortality. ${ }^{16}$

\section{OPEN QUESTIONS}

Given the methodology adopted in most trials, there are some important issues that we could not address properly. Mortality as the end point used in our analysis was unqualified; no information on cause specific or underlying related comorbidity was available. This together with the lack of stratification by patient mix prevents more meaningful conclusions. Subgroup analyses were not possible for all the open questions posed at the recent consensus conference, ${ }^{4}$ including which patient subgroups will benefit most. Even the apparent superiority of combined systemic and topical selective decontamination over topical treatment alone should be interpreted cautiously, as we could not simultaneously control for the possible imbalances in patient mix between the two types of trials. The role of systemic antibiotic alone could not be evaluated: in only two trials $\mathrm{s}^{323}$ the same systemic antibiotic prophylaxis was given to all patients, and consequently we were unable to determine the relative contribution of the two components to the effect of the combination. Finally, the problem of safety in terms of resistance could not be examined, given that this information was lacking in most trials.

\section{METHODOLOGICAL CONSIDERATIONS}

Comment is needed on the statistical method used to combine data across trials and measure treatment benefits. The odds ratio is often used an an approximation of the relative risk in case referent studies. It is also a valid measure of treatment effect in clinical trials. The odds ratio has a distinct statistical advantage over the relative risk in terms of its sampling distribution and suitability for modelling and has become the preferred statistic for pooling data across different trials in the form of meta-analysis. ${ }^{40}$

The major limitation of the odds ratio is its relative insensitivity to the magnitude of risk without treatment. To overcome this problem the "number of patients needing treatment" has been proposed as a measure able to relate treatment burden to therapeutic yields in a clinically relevant manner. ${ }^{14}$ This has the same advantage over the relative risk or the odds ratios of the absolute risk reduction in that it expresses efficacy in a manner that incorporates both the baseline risk without treatment and the risk reduction with treatment. If the event rate in the control group is high even a smaller relative risk reduction will produce a low number to be treated indicative of a favourable yields to burden ratio. Conversely, if the event rate in the control group is low the risk reduction must be large in order to produce a low number of patients needed to be treated. As mentioned above, we calculated these numbers with reference to the value of the common odds ratios. When we consider the heterogeneity of case mix and the above mentioned possibility of a dilution of treatment effect owing to the inclusion of 


\section{Clinical implications}

- Around half of patients who need ventilation in intensive care develop respiratory tract infections

- Respiratory tract infections are thought to be responsible for some excess mortality in intensive care patients

- Selective decontamination of the digestive tract reduces the incidence of respiratory tract infections by $63 \%$

- A full protocol including parenteral and topical antimicrobials may reduce mortality by around $20 \%$, though present evidence does not permit firm conclusions

- The association between respiratory tract infection and mortality seems weak in the heterogeneous populations studied to date

patients with severe underlying diseases (likely to die even if infections are prevented) the lower limit of the range of estimates is probably more realistic than the upper.

\section{Conclusions}

This meta-analysis, although informative, should be seen as an intermediate step in the evolution of selective decontamination. The international collaboration, a very important byproduct, will now pursue a more refined meta-analysis based on individual patient data. For those who believe that the organisation of new trials is the necessary next step this meta-analysis indicates what the sample size (1500-2000 patients) should be of one or more studies properly designed with mortality as the main end point. Two possible strategies should be considered: a single large international study or, more realistically, a series of national, smaller scale prospectively coordinated trials.

What has been achieved should be seen as a direct outcome of the European consensus conference. Without that organisational effort it would have been impossible to undertake such a large internationa collaboration. This is important from a research policy viewpoint, as there is often scepticism about the true value of consensus conferences. If anything, this study suggests that the idea of worldwide collaborative metaanalyses as an essential component of consensus conferences may broaden their impact on research policies well beyond the traditional production and diffusion of recommendations. ${ }^{41}$

We thank D Baxby, G Tognoni, and F R Cockerill III for useful suggestions in the preparation of this manuscript; $J$ Carlet for continuing help in the retrieval of relevant studies; and $\mathrm{Ph}$ Loirat (president), A Bauernfeind, A Binslev, $\mathrm{K}$ Falke, R G Finch, R Launois, M Reynaert, J L Robotham, G Tognoni, A Torres, and J W M Van Der Meer (members of jury), of the first European consensus conference on intensive care medicine, for encouragement.

Participants and collaborating centres: S J A Aerdts and H A L Clasener (Sophia Hospital, Zwolle, the Netherlands); P H B Blair and B J Rowlands (Royal Victoria Hospital, Belfast, Northern Ireland); Ch Brun-Buisson and P Legrand (Hôpital Henri Mondor, Créteil, France); F B Cerra and D Dunn (University Hospital and Clinic, Minneapolis, USA); F R Cockerill III and R L Thompson (Mayo Clinic, Rochester, Minnesota, USA); M Ferrer and A Torres (Hospital Clinic i Provincial, Barcelona, Spain); H Gastinne and $M$ Wolff (French study group on selective decontamination of the digestive tract (France)); Ph Gaussorgues (Hôpital de la Croix-Rousse, Lyon, France); J Godard and J Motin (Hôpital Edouard Herriot, Lyon, France); J M J Hammond and P D Potgieter (Groote Schuur Hospital, Cape Town,
South Africa); G Hunefeld (Evangelisches Krankenhaus, Gottingen-Weende, Germany); S Jacobs and J E Foweraker (University Hospital of Wales, Cardiff); A J H Kerver and J H Rommers (Sint Franciskus Hospital, Rotterdam, the Netherlands); A M Korinek and M J Laisne (Hôpital Pitié-Salpétrière, Paris, France); A Martinez-Pelluz and J Rodriguez-Roldan (General Hospital, Murcia, Spain); M Palomar and F Alvarez (Hospital Vall d'Hebron, Barcelona, Spain); J Pugin and P M Suter (University Hospital, Geneva, Switzerland); L A Rocha and R Villanueva (Hospital Juan Canalejo, La Coruna, Spain); N Rolando and R Williams (King's College Hospital, London); M Sanchez-Garcia and J A Cambronero-Galache (Hospital PPE Asturias, Alcala de Henares, Spain); G W M Tetteroo and H A Bruining (University Hospital Dijkzigt, Rotterdam, the Netherlands); C Ulrich and J E Harinck de Weerd (Westeinde Hospital, The Hague, the Netherlands); K Unertl and K Peter (Klinikum Grosshadern, Munich, Germany); J Verhaegen and L Verwaest (University Hospital, Louvain, Belgium); R Winter and H Humphreys (University Hospital, Nottingham)

Secretariat (coordinators of study and compilers of draft versions of report): A Liberati, $\mathrm{L}$ Brazzi, and $\mathrm{V}$ Torri (Laboratorio di Epidemiologia Clinica, Istituto Mario Negri, Milan, Italy); H K F Van Saene (University of Liverpool, Liverpool); M Langer (Ospedale Maggiore IRCCS, Reparto di Rianimazione, Milan, Italy).

1 Stoutenbeek CP, Van Saene HKF, Miranda DR, Zandstra DF. The effect of selective decontamination of the digestive tract on colonization and infection rate in multiple trauma patients. Intensive Care Med 1984;10:185-92.

2 Vandenbroucke-Grauls CMJE, Vandenbroucke JP. Effects of selective decontamination of the digestive tract on respiratory infections and mortality in the intensive care unit. Lancet 1991;338:859-62.

3 Brazzi L, Liberati A. A review of design and conduct of the available studies on selective decontamination of the digestive tract (SDD). Reanimation Urgences 1992;1:501-7.

4 First European consensus conference in intensive care medicine. Selective digestive decontamination in intensive care unit patients. Intensive Care Med 1992; 18: 182-8.

5 Liberati A, Brazzi L. Effect of selective decontamination of the digestive tract upon mortality. Reanimation Urgences 1992;1:521-5.

6 Godard J, Guillaume C, Reverdy ME, Bachmann P, Bui-Xuan B, Nageotte A et al. Intestinal decontamination in a polyvalent ICU. Intensive Care Med 1990; 16: 307-11

7 Hunefeld G. Klinische Studie zur selektiven Darmdekolonisation bei 204 langzeitbeatmeten abdominal-und unfallchirurgischen Intensivpatienten. Anaesthesiol Reanim 1989;14:131-53.

8 Terteroo GWM, Wagenvoort JHT, Castelein A, Tilanus HW, Ince $C$ Bruining HA. Selective decontamination to reduce Gram-negative colonisation and infections after oesophageal resection. Lancet 1990;335:704-7.

9 Rolando N, Gimson A, Wade J, Philpott-Howard J, Casewell M, Williams R. Prospective controlled trial of selective parenteral and enteral antimicrobia regimen in fulminant hepatic failure. Hepatology 1993;17:196-201

10 Verhaegen J. Randomised study of selective digestive decontamination on colonisation and prevention of infections in mechanically ventilated patient in the ICU. Belgium: University of Louvain, 1992. ( $\mathrm{PhD}$ thesis.)

11 Gaussorgues Ph, Salord F, Sirodot M, Tigaud S, Cagnan S, Gerard M, et al. Efficacité de la décontamination digestive sur la survenue des bactériémies nosocomiales chez les patients sous ventilation mécanique et recevant des bêtamimétiques. Reanimation Soins Intensifs Medicine D'Urgence 1991;7: 169-74.

12 Antiplatelet Trialists' Collaboration. Secondary prevention of vascular disease by prolonged antiplatelet treatments. BMF 1988;296:320-31.

13 DerSimonian R, Laird N. Meta-analysis in clinical trials. Controlled Clin Trials 1986;7:177-88.

14 Laupacis A, Sackett DL, Roberts RS. An assessment of clinically useful measures of the consequences of treatment. $N$ Engl F Med 1988;318:172833.

15 Vellerman PF, Welsh RE. Efficient computing of regression diagnostic American Statistician 1981;35:234-42.

16 Van Saene HKF, Stoutenbeek CP, Stoller JK. Selective decontamination of the digestive tract in the intensive care unit: current status and future prospects. Crit Care Med 1992;20:691-703.

17 Cockerill FR III, Muller SR, Anhalt JP, Marsh HM, Farnell MB, Mucha P, et al. Prevention of infection in critically ill patients by selective decontamination of the digestive tract. Ann Intern Med 1992;117:545-53.

18 Gastinne H, Wolff M, Delatour F, Faurisson F, Chevret S. A controlled tria in intensive care units of selective decontamination of the digestive tract with nonabsorbable antibiotics. N Engl F Med 1992;326:594-9.

19 Korinek AM, Laisne MJ, Nicolas MH, Raskine L, Deroin V, Sanson-Lepors MJ. Selective decontamination of the digestive tract in neurosurgical intensive care unit patients. Crit Care Med (in press).

20 Rocha LA, Martin MJ, Pita S, Paz J, Seco C, Margusino L, et al. Prevention of nosocomial infection in critically ill patients by selective decontamination of the digestive tract. Intensive Care Med 1992;18:398-404.

21 Aerdts SJA, van Dalen R, Clasener HAL, Festen J, van Lier HJJ, Vollaard EJ. Antibiotic prophylaxis of respiratory tract infection in mechanically ventilated patients. Chest 1991;100:783-91.

22 Blair P, Rowlands BJ, Lowry K, Webb H, Armstrong P, Smilie J. Selective decontamination of the digestive tract: a stratified, randomized, prospective study in a mixed intensive care unit. Surgery 1991;110:303-10.

23 Cerra FB, Maddaus MA, Dunn DL, Wells CL, Konstantinides NN, Lehmann SL, et al. Selective gut decontamination reduces nosocomial infections and length of stay but not mortality or organ failure in surgical intensive care unit patients. Arch Surg 1992;127:163-9.

24 Jacobs S, Foweraker JE, Roberts SE. Effectiveness of selective decontamination of the digestive tract (SDD) in an ICU with a policy encouraging a low gastric pH. Clinical Intensive Care 1992;3:52-8.

25 Palomar M, Barcenilla F, Alvarez F, Nava J, Triginer C, Jordà R, et al. 
Prevenciòn de la neumonìa nosocomial: descontaminaciòn digestiva selectiva y sulcralfato. Medicina Intensiva 1992;16:81-5.

26 Pugin J, Auckenthaler R, Lew DP, Suter PM. Oropharyngeal decontamination decreases incidence of ventilator-associated pneumonia. $\$ A M A 1991$; 265:2704-10.

27 Ulrich C, Harinck-deWeerd JE, Bakker NC, Jacz K, Doornbos L, de Ridder VA. Selective decontamination of the digestive tract with norfloxacin in the prevention of ICU-acquired infections: a prospective randomized study. Intensive Care Med 1989;15:424-31.

28 Unert K, Ruckdeschel G, Selbmann HK, Jensen U, Forst H, Lenhart FP, et al. Prevention of colonization and respiratory infections in long-term ventilated patients by local antimicrobial prophylaxis. Intensive Care Med 1987;13:106-13.

29 Winter R, Humphreys H, Pick A, MacGowan AP, Willatts SM, Speller DCE. A controlled trial of selective decontamination of the digestive tract in intensive care and its effect on nosocomial infection. $f$ Antimicrob Chemother 1992;30:73-87.

30 Sanchez M, Cambronero JA, Lopez G, Cerda E, Rodriguez JM, Rubio J, et al. Selective decontamination of the digestive tract in intubated patients: a multicentric, double-blind, placebo controlled study. In: Proceedings of the 32nd Interscience Conference on Antimicrobial Agents and Chemotherapy. Anaheim, California: ICAAC, 1992.

31 Brun-Buisson C, Legrand P, Rauss A, Richard C, Montravers F, Besbes M, et al. Intestinal decontamination for control of nosocomial multiresistant Gram-negative bacilli. Ann Intern Med 1989;110:873-81.

32 Hammond JMJ, Potgieter PD, Saunders GL, Forder AA. Double-blind study of selective decontamination of the digestive tract in intensive care. Lancet 1992;340:5-9.
33 Kerver AJH, Rommes JH, Mevissen-Verhage EAE, Hulstaert PF, Vos A Verhoef $\mathrm{J}$, et al. Prevention of colonization and infection in critically il patients: a prospective randomized study. Crit Care Med 1988;16:1087-93.

34 Rodriguez-Roldàn JM, Altuna-Cuesta A, Lopez A, Carrillo A, Garcia J, Leo $\mathrm{J}$, et al. Prevention of nosocomial lung infection in ventilated patients: use of an antimicrobial pharyngeal nonabsorbable paste. Crit Care Med 1990;18: 1239-42.

35 Ferrer M, Torres A, Gonzàlez J, Puig de la Bellacasa J, Gatell JM, Jiménez MT, et al. Utility of selective digestive decontamination in a genera population of mechanically ventilated patients. Am Rev Respir Dis 1992;145 A112.

36 Begg CB. A measure to aid in the interpretation of published clinical trials. Stat Med 1985;4:1-9.

37 Webb $\mathrm{CH}$. Antibiotic resistance associated with selective decontamination of the digestive tract. $\mathcal{F}$ Hosp Infect 1992;22:1-5.

38 Van Saene HKF, Unertl KE, Alcock SR, Stoutenbeek CP, Hart CA. Emergence of antibiotic resistance during selective digestive decontamination? I Hosp Infect 1993;24: 158-62.

39 Stewart LA, Parmar MKB. Meta-analysis of the literature or of individu patient data: is there a difference? Lancet 1993;341:418-22.

40 Boissel JP, Blanchard J, Panak E, Peyrieux JC, Sacks H. Considerations for the meta-analysis of randomized clinical trials. Controlled Clin Trial 1989;10:254-81.

41 McGlynn EA, Kosekoff J, Brook RH. Format and conduct of consensus development conferences; multinational comparison. Int $\mathcal{f}$ Technol Assess Health Care 1990;6:450-69.

(Accepted 17 fune 1993)

\title{
Termination of pregnancy with reduced doses of mifepristone
}

\author{
World Health Organisation Task Force on Post-ovulatory Methods of Fertility Regulation
}

\section{Abstract}

Objectives-To compare the abortifacient efficacy and side effects of three doses of the antiprogestin mifepristone plus prostaglandin for termination of early pregnancy.

Design-Randomised, double blind multicentre trial.

Setting-11 departments of obstetrics and gynaecology and of family planning, mostly in university hospitals, in seven countries.

Subjects-1182 women with an early pregnancy (menstrual delay of 7-28 days) requesting abortion.

Interventions-Single doses of $200 \mathrm{mg}, 400 \mathrm{mg}$, or $600 \mathrm{mg}$ mifepristone followed, 48 hours later, by vaginal pessary of $1 \mathrm{mg}$ of the prostaglandin $E_{1}$ analogue gemeprost.

Main outcome measures-Outcome of treatment; duration and subjective amount of menstrual bleeding; side effects and complications; and concentrations of haemoglobin.

Results-Outcome was similar with the three doses of mifepristone. Of the 1151 women with known outcome, $95 \cdot 5 \%$ had a complete abortion (364 $(93.8 \%)$ of those given $200 \mathrm{mg}$ mifepristone, 368 $(94 \cdot 1 \%)$ of those given $400 \mathrm{mg}$, and $367(94 \cdot 3 \%)$ of those given $600 \mathrm{mg}$ ), $3.7 \%$ had an incomplete abortion (14 (3.6\%), $15(3.8 \%)$, and $14(3.6 \%)), 0.3 \%$ had a missed abortion (three $(0.8 \%)$, one $(0.3 \%)$, and none), and $0.4 \%$ had a continuing live pregnancy (two $(0.5 \%)$, two $(0.5 \%)$, and one $(0.3 \%))$. Of the 43 women who had incomplete abortion, 23 underwent emergency uterine curettage (usually for haemostatic purposes) and three of these women were given a blood transfusion. The numbers of reported complaints, bleeding patterns, and changes in blood pressure and haemoglobin concentrations were similar with the three treatments.

Conclusions-For termination of early pregnancy a single dose of $\mathbf{2 0 0} \mathbf{~ m g}$ mifepristone is as effective as the currently recommended dose of $600 \mathrm{mg}$ when used in combination with a vaginal pessary of $1 \mathrm{mg}$ gemeprost.

\section{Introduction}

The antiprogestin mifepristone (RU 486; 11 $\beta$-[p(dimethylamino)-phenyl]-17 $\beta$-hydroxy-17-[1- propynyl] estra-4,9-dien-3-one) has been registered for termination of early pregnancy in France and China since September 1988, in Great Britain since July 1991 and in Sweden since September 1992. In France and China mifepristone can be used for inducing abortion in pregnancies of up to seven weeks of amenorrhoea, while in Britain and Sweden it can be used in pregnancies of up to nine weeks of amenorrhoea. In all four countries the recommended treatment is a single dose of $600 \mathrm{mg}$ mifepristone (three tablets of $200 \mathrm{mg}$ ) followed 36-48 hours later by a suitable prostaglandin analogue with uterotonic activity (such as a vaginal suppository of gemeprost or oral tablets of misoprostol), and this combination gives complete abortion in $95-96 \%$ of cases. ${ }^{1}$ In the largest series reported to date efficacy was $95 \cdot 3 \%$ among 15709 women treated in France with vaginal gemeprost or intramuscular sulprostone as the prostaglandin. ${ }^{2}$ The failures consisted of persisting pregnancies $(1 \cdot 2 \%)$, incomplete expulsion $(2 \cdot 8 \%)$, and women requiring a haemostatic surgical procedure $(0 \cdot 7 \%)$.

Several studies conducted on the pharmacokinetics of orally administered mifepristone indicate that concentrations of the antiprogestin in the blood do not increase proportionally with increasing oral doses. This is probably because in humans mifepristone is bound to $\alpha_{1}$ acid glycoprotein, which acts as a low affinity carrier protein. The carrying capacity of $\alpha$ acid glycoprotein is limited so that plasma levels of mifepristone correlate with the concentration of this protein rather than the administered dose. ${ }^{4}$ From these studies it seemed likely that the percentage of successful abortions achieved by a single dose of $600 \mathrm{mg}$ mifepristone could be obtained with smaller doses of the antiprogestin. Support for this assumption is provided by studies conducted under the auspices of the World Health Organisation, ${ }^{56}$ including a recent randomised multicentre trial in which five $25 \mathrm{mg}$ doses of mifepristone given at 12 hour intervals were shown to be as effective as the recommended single dose of $600 \mathrm{mg} .{ }^{7}$ Rodger and Baird administered single doses of $600 \mathrm{mg}, 500 \mathrm{mg}$, and $400 \mathrm{mg}$ of mifepristone and reported rates of complete abortion of $100 \%, 97 \%$, and $90 \%$ respectively. ${ }^{8}$ The number of women in each group was too small, however, to assess if the apparent downward trend was statistically significant.

The purpose of the present randomised, double
Dr P F A Van Look Research, Development and Avenue Appia,

Switzerland. 